\title{
Sero-prevalence of Hepatitis B Surface Antigen (HBsAg) amongst Pregnant Women Attending Antenatal Clinic at the Federal Medical Centre Umuahia, Abia State, Nigeria
}

\author{
Onwuakor C.E ${ }^{1, *}$, Eze V.C ${ }^{1}$, Nwankwo I.U ${ }^{1}$, Iwu J.O \\ ${ }^{1}$ Department of Microbiology, College of Natural Sciences, Michael Okpara University of Agriculture Umudike, Abia State, Nigeria \\ ${ }^{2}$ Department of Accident \& Emergency, Federal Medical Centre, Umuahia, Abia State, Nigeria \\ *Corresponding author: chijiokeonwuakor@gmail.com
}

Received October 08, 2014; Revised November 22, 2014; Accepted December 25, 2014

\begin{abstract}
Despite the existence of a safe and effective vaccine, Nigeria has remained a hyper-endemic area for hepatitis B virus infection, with estimated $12 \%$ of the total population being chronic carriers. Neonates who contact hepatitis B virus infection will have an almost 90\% risk of developing chronic hepatitis B surface antigen (HBsAg) carrier state and chronic liver disease. The objectives of this study were to determine the sero-prevalence of hepatitis B surface antigen among pregnant women and identifying potential risk factors associated with the infection. This study involved a total of 350 pregnant women who attended antenatal at the Federal medical Centre, Umuahia, Abia State, Nigeria. Blood samples from all consenting pregnant women were collected. A structured pro forma designed for this purpose was used to obtain socio-demographic information and the presence of risk factors. Data collated was analyzed using GraphPad Prism statistical software with $\mathrm{P}<0.05$ at $95 \%$ confidence interval. The results showed that HBsAg sero-prevalence rate of $7.1 \%$ was observed in all the pregnant women tested. Sero-prevalence of $\mathrm{HBsAg}$ amongst parturients were more in patients within their first trimesters (11.1\%), Primigravida pregnant women (8.0\%), women with history of dental or surgical procedures (34.0\%) and multiple sexual partners (25.0\%) and in women with no formal education (37.5\%). An intermediate prevalence of HBsAg was identified which justifies the need for routine screening in pregnancy in order to identify and treat the infection, thus reducing the risk of transmission of the virus. Contraceptive options aimed at prevention of pregnancy and sexually transmitted infection (STI) should be encouraged.
\end{abstract}

Keywords: sero-prevalence, surface antigen, pregnant women, antenatal, Federal Medical Centre, Umuahia

Cite This Article: Onwuakor C.E, Eze V.C, Nwankwo I.U, and Iwu J.O, "Sero-prevalence of Hepatitis B Surface Antigen (HBsAg) amongst Pregnant Women Attending Antenatal Clinic at the Federal Medical Centre Umuahia, Abia State, Nigeria.” American Journal of Public Health Research, vol. 2, no. 6 (2014): 255-259. doi: 10.12691/ajphr-2-6-7.

\section{Introduction}

The hepatitis B virus (HBV) is estimated to chronically infect 350 million people worldwide [1] of whom 65 million live on the African continent. Sub-Saharan Africa has a high endemicity, and more than 50 million people are believed to be chronic carriers of the HBV [2]. HBV is resistant to breakdown, can survive outside the body, and is easily transmitted through contact with infected body fluids [3]. The prevalence of chronic hepatitis B infection varies greatly around the world and is closely associated with the main routes of HIV transmission [4] Modes of transmission of hepatitis B vary, since the virus is present in blood, saliva, semen, vaginal secretions, menstrual blood, and in smaller quantities in perspiration, breast milk, tears and urine of the infected individual [4].
Diagnosis of HBV infection is usually through serological and virological markers. Hepatitis B surface antigen (HBsAg) is the hallmark of HBV infection and is the first serological marker to appear in acute $\mathrm{HBV}$ infection, and persistence of HBsAg for more than 6 months suggests chronic HBV infection [5]. Globally, over 2 billion people are infected with the virus and over 350 million have chronic infection [6]. Infection with this virus does not only leads to acute illnesses, but also to chronic illnesses like liver cirrhosis and hepatocellular carcinoma which accounts for more than 1 million deaths globally [6,7]. The prevalence of hepatitis B virus infection is relatively high in Africa, having the second highest number of chronically HBV-infected individuals [8].

Acute HBV infection occurs in 1 to 2 of every 1000 pregnancies with 1 to $5 \%$ of pregnant women being chronic carriers of HBV [9]. If the acute maternal infection occurs in the first trimester and resolves, the risk 
of neonatal infection is minimal. However, an infection during the second and third trimester poses a threat of $10 \%$ and $90 \%$, respectively for vertical transmission [10]. The risk of transmission depends on the degree of maternal infectivity and the genomic type of the virus [11]. These babies are at serious risk of developing chronic liver disease, cirrhosis of the liver and hepatocellular carcinoma in later life and up to $25 \%$ of them will die as adults due to liver disease [12]. There are three mechanisms of HBV trans-mission from HBsAg-positive mothers: (i) trans-placental intra-uterine transmission; (ii) transmission during delivery by contact with maternal infected fluids in the birth canal; and (iii) post natal transmission from mothers to infants during child care or through breastfeeding [13]. Vertical transmission has been reported in $90 \%$ of infants born to HBsAg positive mothers [14,15].

Nigeria is classified among the group of countries endemic for HBV infection with a current infected population of 18 million [16]. Despite the existence of a safe and effective vaccine, Nigeria has remained a hyperendemic area for HBV infection, with an estimated 12\% of the population being chronic carriers [17]. Seroprevalence studies on HBsAg in Nigeria have shown that the prevalence of the infection in pregnant women ranges from 2 to 15.8\% [16,18,19,20]. Even though studies have been carried out on HBV infection in different parts of Nigeria, and in different sub-groups of individuals, the prevalence among pregnant women and information regarding the vertical transmission rate is scanty from the South-South region of the country. Since most transmission occurs intra-partum, this study is aimed at determining the sero-prevalence of HBsAg at delivery and the rate of vertical transmission. It will also show the risk factors associated with maternal infection.

The aim of this study was to determine the maternal sero-prevalence of HBsAg amongst parturients. The specific objectives were: (1) to find out the prevalence of $\mathrm{HBV}$ in pregnant women presented in labour to the Federal Medical Center Umuahia, Abia State, Nigeria, (2) to determine the age group with the highest prevalence of HBV infection and some demographic characteristics such as marital status, education and occupation of the women with highest prevalence of $\mathrm{HBV}$, (3) to investigate possible predisposing factors for $\mathrm{HBV}$ among these women and (4) to determine the gestational age and parity of the women with the highest prevalence of HBV.

\section{Methodology}

\subsection{Study Area}

This study was carried out at the Federal Medical Centre Umuahia, Abia State of Nigeria from 12th July to 20th November, 2013.

\subsection{Study Design}

This was an observational cross-sectional study involving all pregnant women presented in labour to the Federal Medical Centre Umuahia, Abia State of Nigeria. The purpose of the study was duly explained to the participants prior to the study at the antenatal clinic and an informed consent was obtained, this was indicated on their antenatal cards and their socio-demographic characteristics and risk factors for HBV infection were documented in a structured preforma for each participant.

\subsubsection{Inclusion Criterion}

The inclusion criteria for the study was any pregnant woman who gave consent to participate in the study. This research was conducted after approval was obtained from the Ethics and research Committee of the hospital. Women who came to antenatal clinic and consented to screening were directed to the hospital's laboratory. There blood samples were collected and processed. Part of the sera collected was tested for HBsAg using Quick Test ${ }^{\mathrm{TM}}$ HBsAg Serum/Plasma/Whole Blood Rapid Test Strip (Acon Biotech Diagnostic Systems, USA) in the laboratory. Reactive sample were further confirmed for HBsAg using Smart Check HBsAg immunoassay Kit (GlobalMed, South Africa).

\subsubsection{Exclusion Criterion}

Those excluded from the study are: patients who withheld their consent for inclusion in the study; those immunized against hepatitis B infection (information obtained by verbal confirmation of previous immunization); and patients with HIV comorbidities were excluded.

\subsection{Data Collection and Analysis}

Data of women screened from 12th July to 20th November, 2013 were included. A chart review of the women who were found to be HBsAg-positive was conducted and the following variables noted: age group, gestational age, parity, history with potential risk factors, marital status, educational status and occupation. The data were analyzed using Chi-Square test method where $\mathrm{P}$ value 0.05 or less was considered significant, using GraphPad Prism Version 6.0.

\section{Results}

Three hundred and fifty women were enrolled into the study during the four month period from 12th July to 20th November, 2013. Of these, 25 tested positive to HBsAg, giving a sero-prevalence rate of $7.1 \%$ in the study population. A total of 25 (7.1\%) of the pregnant women tested positive for HBsAg. Pregnant women of age group 29-31 years had the highest prevalence (9.6\%) of HBsAg (Table 1).

Table 1. Prevalence of HBsAg in Relation to Age of the Pregnant Women

\begin{tabular}{cccc}
\hline $\begin{array}{c}\text { Age Group } \\
\text { (Years) }\end{array}$ & $\begin{array}{c}\text { Number } \\
\text { Examined }\end{array}$ & $\begin{array}{c}\text { Number HBsAg } \\
\text { Positive (\%) }\end{array}$ & $\begin{array}{c}\text { Number HBsAg } \\
\text { Negative (\%) }\end{array}$ \\
\hline $17-21$ & 15 & $1(6.7)$ & $14(93.3)$ \\
$22-26$ & 98 & $4(4.1)$ & $94(95.9)$ \\
$27-31$ & 156 & $15(9.6)$ & $141(91.4)$ \\
$32-36$ & 54 & $4(7.4)$ & $50(92.6)$ \\
$37-41$ & 25 & $1(4.0)$ & $24(96.0)$ \\
$42-46$ & 2 & $0(0.0)$ & $2(100.0)$ \\
Total & $\mathbf{3 5 0}$ & $\mathbf{2 5}(\mathbf{7 . 1})$ & $\mathbf{3 2 5}(\mathbf{9 2 . 9 )}$ \\
\hline
\end{tabular}


Table 2. Prevalence of HBsAg in Relation to Gestational Age of the Pregnant Women

\begin{tabular}{lccc}
\hline Trimester & $\begin{array}{c}\text { Number } \\
\text { Examined }\end{array}$ & $\begin{array}{c}\text { Number HBsAg } \\
\text { Positive (\%) }\end{array}$ & $\begin{array}{c}\text { Number HBsAg } \\
\text { Negative (\%) }\end{array}$ \\
\hline First & 162 & $18(11.1)$ & $144(88.9)$ \\
Second & 118 & $5(4.2)$ & $113(95.8)$ \\
Third & 70 & $2(2.9)$ & $68(97.1)$ \\
Total & $\mathbf{3 5 0}$ & $\mathbf{2 5 ( 7 . 1 )}$ & $\mathbf{3 2 5}(\mathbf{9 2 . 9 )}$ \\
\hline
\end{tabular}

Table 2 shows high prevalence rate of HBsAg among the women in the first trimester of their pregnancy 18 (11.1\%) and least in the third trimester 2 (2.9\%). There was significant association between HBsAg and gestational ages $(\mathrm{P}<0.05)$. Women positive to HBsAg was seen to be highest among the Primigravida 18 (8.0\%) than among the Multigravida 7 (5.6\%). However, there was no significant relationship between them $(\mathrm{P}>0.05)$ Table 3 .

Table 3. Prevalence of HBsAg in Relation to Parity of the Pregnant Women

\begin{tabular}{lccc}
\hline Parity & $\begin{array}{c}\text { Number } \\
\text { Examined }\end{array}$ & $\begin{array}{c}\text { Number HBsAg } \\
\text { Positive (\%) }\end{array}$ & $\begin{array}{c}\text { Number HBsAg } \\
\text { Negative (\%) }\end{array}$ \\
\hline Primigravida & 226 & $18(8.0)$ & $208(92.0)$ \\
Multigravida & 124 & $7(5.6)$ & $117(94.4)$ \\
Total & $\mathbf{3 5 0}$ & $\mathbf{2 5 ( 7 . 1 )}$ & $\mathbf{3 2 5}(\mathbf{9 2 . 9 )}$ \\
\hline
\end{tabular}

Table 4 shows HBsAg sero-prevalence among the pregnant women in relation to some risk factors. There was significant relationship between the women who had history of tattoos/tribal marks $6(17.6 \%)$ and those who had not $19(6.0 \%)$ and women who had history of surgical and dental procedures 19 (34.0\%) and those who had not 6 $(2.0 \%)(\mathrm{P}<0.05)$. There was significant association seen among the women who had history of multiple sexual partners although high prevalence was seen among the women who had multiple sexual partners 2 (25.0\%) than those who had not 27 (7.9\%). Likewise women who had history of previous blood transfusion showed high prevalence rate of HBsAg 8 (28.6\%) than those who did not 17 (5.3\%).

Table 4. Prevalence of HBsAg in Relation to Some Risk Factors of the Pregnant Women

\begin{tabular}{|c|c|c|c|}
\hline Trimester & $\begin{array}{c}\text { Number } \\
\text { Examined }\end{array}$ & $\begin{array}{c}\text { Number HBsAg } \\
\text { Positive (\%) }\end{array}$ & $\begin{array}{c}\text { Number HBsAg } \\
\text { Negative (\%) }\end{array}$ \\
\hline \multicolumn{4}{|c|}{$\begin{array}{l}\text { History of } \\
\text { tattoos/tribal } \\
\text { marks }\end{array}$} \\
\hline Yes & 34 & $6(17.6)$ & 28(82.4) \\
\hline No & 316 & $19(6.0)$ & $297(94.0)$ \\
\hline \multicolumn{4}{|c|}{$\begin{array}{l}\text { History of } \\
\text { surgical and } \\
\text { dental procedures }\end{array}$} \\
\hline Yes & 56 & $19(34.0)$ & $37(66.0)$ \\
\hline No & 294 & $6(2.0)$ & 288(98.0) \\
\hline \multicolumn{4}{|c|}{$\begin{array}{l}\text { History of } \\
\text { multiple sexual } \\
\text { partners }\end{array}$} \\
\hline Yes & 8 & $2(25.0)$ & $6(75.0)$ \\
\hline No & 342 & 23(6.7) & 319(93.3) \\
\hline $\begin{array}{l}\text { Total } \\
\text { History of } \\
\text { previous b } \\
\text { transfusior }\end{array}$ & 350 & 25 (7.1) & 325 (92.9) \\
\hline Yes & 28 & $8(28.6)$ & $20(71.4)$ \\
\hline No & 322 & $17(5.3)$ & $305(94.7)$ \\
\hline Total & 350 & $25(7.1)$ & 325 (92.9) \\
\hline
\end{tabular}

Table 5 shows that HBsAg positivity was seen to be higher among married pregnant women 24 (7.2\%) than the unmarried 1 (6.7\%). However, there was no significant relationship between them $(\mathrm{P}>0.05)$.

Table 5. Prevalence of HBsAg in Relation to Marital Status of the Pregnant Women

\begin{tabular}{lccc}
\hline $\begin{array}{l}\text { Marital } \\
\text { status }\end{array}$ & $\begin{array}{c}\text { Number } \\
\text { Examined }\end{array}$ & $\begin{array}{c}\text { Number HBsAg } \\
\text { Positive (\%) }\end{array}$ & $\begin{array}{c}\text { Number HBsAg } \\
\text { Negative (\%) }\end{array}$ \\
\hline Unmarried & 15 & $1(6.7)$ & $15(93.8)$ \\
Married & 335 & $24(7.2)$ & $445(91.9)$ \\
Total & $\mathbf{3 5 0}$ & $\mathbf{2 5 ( 7 . 1 )}$ & $\mathbf{3 2 5 ( 9 2 . 9 )}$ \\
\hline
\end{tabular}

Table 6. Prevalence of HBsAg in Relation to Educational Status of the Pregnant Women

\begin{tabular}{lccc}
\hline $\begin{array}{l}\text { Educational } \\
\text { status }\end{array}$ & $\begin{array}{c}\text { Number } \\
\text { Examined }\end{array}$ & $\begin{array}{c}\text { Number HBsAg } \\
\text { Positive (\%) }\end{array}$ & $\begin{array}{c}\text { Number } \\
\text { HBsAg } \\
\text { Negative (\%) }\end{array}$ \\
\hline No formal & 8 & $3(37.5)$ & $5(62.5)$ \\
Education & 4 & $1(25.0)$ & $3(75.0)$ \\
Primary School & 290 & $13(4.5)$ & $277(95.5)$ \\
Secondary School & 48 & $8(16.7)$ & $40(83.3)$ \\
Tertiary & $\mathbf{3 5 0}$ & $\mathbf{2 5}(\mathbf{7 . 1 )}$ & $\mathbf{3 2 5}(\mathbf{9 2 . 9 )}$ \\
Total & &
\end{tabular}

Table 6 shows high prevalence rate of HBsAg among women with no formal education 3 (37.5\%) than the other classes of educational levels. Prevalence of HBsAg in relation to occupation of the pregnant women studied is shown in Table 7 . Housewives had the highest prevalence rate of $7(14.6 \%)$.

Table 7. Prevalence of HBsAg in Relation to Occupation of the Pregnant Women

\begin{tabular}{lccc}
\hline Occupation & $\begin{array}{c}\text { Number } \\
\text { Examined }\end{array}$ & $\begin{array}{c}\text { Number } \\
\text { HBsAg } \\
\text { Positive (\%) }\end{array}$ & $\begin{array}{c}\text { Number HBsAg } \\
\text { Negative (\%) }\end{array}$ \\
\hline Traders & 225 & $12(5.3)$ & $213(94.7)$ \\
Students & 32 & $3(9.4)$ & $29(90.6)$ \\
Civil servants & 25 & $2(8.0)$ & $23(92.0)$ \\
Health workers & 5 & $0(0.0)$ & $5(100.0)$ \\
Housewives & 48 & $7(14.6)$ & $41(85.4)$ \\
Teachers & 15 & $1(6.7)$ & $14(93.3)$ \\
Total & $\mathbf{3 5 0}$ & $\mathbf{2 5 ( 7 . 1 )}$ & $\mathbf{3 2 5}(\mathbf{9 2 . 9 )}$ \\
\hline
\end{tabular}

\section{Discussion}

The overall prevalence of HBsAg in pregnant women from Umuahia and its neighboring towns was 7.1\%. This places Abia State, specifically Umuahia region, as an endemic area (2-7\% of HBsAg positive) for $\mathrm{HBV}$ infection according to WHO criteria [21]. Since there are no previous data from our study area we are unable to compare for trend. However, there were two earlier studies conducted among pregnant women in other parts of Nigeria which was a little higher than our result [18], but higher than some previous studies in Nigeria $[14,15,16]$. The highest prevalence of HBV infection was found among pregnant women of 27 to 31 years of age (9.6\%), followed closely by ages 17 to 21 years $(6.7 \%)$ and the lowest among those between 42 to 46 years of age $(0.0 \%)$. This correlates with peak age of highest sexual activity in the society and supports the role of sexual intercourse in transmission of HBV. These could be explained by the relationship between hepatitis infection and high risk sexual practices which is noted to be higher 
amongst the younger age group. Similar results were obtained in Zaria and Ethiopia [17,22].

The first trimester pregnancies showed the highest prevalence rate $(11.1 \%)$ and lowest in the third trimester (2.9\%). HBsAg prevalence was statistically significant in the gestational age group of the pregnant women $(\mathrm{P}<0.05)$. This agrees with the findings of [23] that HBsAg prevalence decreases with increase in gestational period among pregnant women attending antenatal clinic.

The prevalence rate of HBsAg among pregnant women with respect to risk factors, including tattooing, dental and surgical procedures, multiple sexual partners and blood transfusion, showed highest prevalence rate (34.0\%) among women that have undergone dental or other forms of surgical procedures, while those that have been involved in tattooing had the least prevalence rate (17.6\%). The result showed that there was an association with HBV infection and those women that had history with these risk factors. An obvious observation of the four fold risk of acquiring hepatitis B infection amongst women having more than one sexual partner was noted in this study $(\mathrm{P}<0.05)$. This brings to light the need to advice strongly against such high risk behaviors amongst parturients. Several studies have shown that vertical transmission of HBV can occur $[20,24,25]$. These differences should be confirmed in further studies. This study showed an intermediate prevalence of HBsAg among the pregnant women, yet, known predisposing factors to HBV infection showed statistically significant association. Also, instrumentation during abortion and related activities may serve as sources of exposure since most terminations are done by unskilled persons using contaminated instruments and surfaces [22].

Inverse relationship between educational status and HBsAg positivity with less educated women showing the highest prevalence rate (37.5\%) had been noted [6,14,18]. However, in this study, it was noted that educational attainment did not reduce the risk factors for transmission of the infection. This brings to light the need for focused education on prevention of high risk behaviors amongst the educated.

One would have expected HBsAg prevalence to be higher in Multigravida women, because of repeated risk of exposure to contaminated surfaces and instruments during delivery [14]. However, the reverse was the case as the prevalence was significantly higher in Primigravida women. The reason for this may be because most of the Primigravida women (8.0\%) had had a termination of pregnancy and had more number of sexual partners in the past which could have exposed them to the virus as compared to the Multigravidae women in monogamous relationships.

This study has some limitations and issues attracting criticisms. The tool of laboratory analysis, serology by rapid test kit, is less sensitive than amplification assays (liquid phase hybridization, antibody capture approach, branched DNA) and DNA amplification tests based on the polymerase chain reaction which are now considered the gold standard in the diagnosis of HBV infection. These tests are expensive and are not available in most centers. Nevertheless, rapid tests can be used as a screening tool in order to identify those women that would require confirmation of their status and further management.

\section{Conclusion}

Preventive measures should be taken against unwanted pregnancies, sexually transmitted infections and multiple sexual partners as these are all routes of transmission of the virus. Sensitization on risk factors and routine screening for $\mathrm{HBV}$ in pregnant women is strongly advocated to reduce morbidity and treatment of $\mathrm{HBV}$ infection in pregnancy to reduce mother-to-child transmission. Availability and accessibility of hepatitis B immunoglobulin to babies born to HBsAg-positive mothers by Government and Non-governmental organizations is also suggested.

\section{Acknowledgement}

We wish to acknowledge the contribution and support of all management staff and nurses associated with the maternity section of the Federal Medical Centre Umuahia, Abia State, Nigeria.

\section{References}

[1] Goldstein, S,T., Zhou, F., Hadler, S.C., Bell, B.P., Mast, E.E and Margolis, H.S, “A mathematical model to estimate global hepatitis B disease burden and vaccination impact”, Int. J. Epidemol. 2005, 34(6): 1329-1339.

[2] Burnett, R., Francois, G and Kew, G, "Hepatitis B virus and human immunodeficiency virus co-infection in sub-Saharan Africa: a call for further action”. Liver Int. 2005, 25: 201-213.

[3] Lavanchy, D, "Hepatitis B virus epidemiology, disease burden, treatment, and current and emerging prevention and control measures”. J. Viral Hep. 2004, 11: 97-107.

[4] Maddrey, W.C, 'Hepatitis B: an important public health issue”. $J$. Med. Virol. 2000, 61: 362-366.

[5] Kao, J.H, "Diagnosis of hepatitis B virus infection through serological and viral markers”. Expert Rev. Gastroenterol. Hepatol. 2008, 2(4): 504-62.

[6] Eke, A.C., Eke, U.A., Okafor, C.I., Ezebialu, I.U and Ogbuagu, C, "Prevalence, correlates and pattern of Hepatitis B surface antigen in a low resource setting”. Virol. J. 2011, 8: 12.

[7] El-Magrahe, H., Furarah, A.R., El-Figih, K., El-Urshfany, S, and Ghenghesh, K.S, "Maternal and neonatal seroprevalence of Hepatitis B surface antigen (HBsAg) in Tripoli, Libya”. J. Infect. Dis. Dev. Ctries, 2010, 4: 168-170.

[8] Mbaawuaga, E.M., Enenebeaka, M.N.O., Okopi, J.A and Damen, J.G, "Hepatitis B virus infection (HBV) among pregnant women in Makurdi, Nigeria”. Afr. J. Biol. Res. 2008, 11:155-159.

[9] Ugwuja, E.I., "Seroprevalence of Hepatitis B surface antigen and liver function tests among adolescents in Abakaliki, Southern Nigeria”. Int. J. Trop. Med. 2010, 6(2):1-6.

[10] Obi, C.L., Nnatu, S.N., Anyiwo, C.E., Agbonlahor, D.E., Esuneh, F.I and Karpos, A, "A comparison of HIV seropositivity and Hepatitis B surface antigenaemia (HBsAg) among the same group of apparently healthy pregnant women in Lagos, Nigeria: a preliminary report”. Viral Immunol. 1993, 6(1): 43-47.

[11] Ezegbudo, C.N., Agbonlahor, D.E., Nwobu, G.O., Igwe, C.U., Agba, M.I and Okpala, H.O, "The seroprevalence of Hepatitis B surface antigen and Human immunodeficiency virus (HIV) among pregnant women in Anambra State”. Shiraz E-medical J. 2004, 5(2): 1-8.

[12] Baba, M.M., Onwuka, I.S and Baba, S.S, "Hepatitis B and C infections among pregnant women in Maiduguri, Nigeria”. Central Eur. J. Pub. Health. 1999, 7(2): 60-62.

[13] Chen, C and Chang, M, "Hepatitis B and pregnancy; The scientific basis for perinatal prevention”. Cambridge J. Online, 2010, 21: 89-113.

[14] Pennap, G.R., Osanga, E.T and Ubam, A, "Seroprevalence of hepatitis B surface antigen among pregnant women attending antenatal clinic in Federal Medical Center, Keffi, Nigeria'. Res. J. Med. Sci. 2011, 51(2):80-82. 
[15] Akani, C.I., Ojule, A.C., Opurum, H.C and Ejilemele, A.A "Seroprevalence of HbsAg in pregnant women in Port Harcourt, Nigeria”. Postgrad Med. J. 2005, 12 (4): 266-270.

[16] Ojo, O.O and Anibijuwon, I.I, "Determination of antibodies to hepatitis B virus in pregnant women in Akure, Ondo state, Nigeria”. Cont. J. Microbiol. 2009, 3: 6-10.

[17] Jatau, E.D and Yabaya, A, "Seroprevalence of hepatitis B virus in pregnant women attending a clinic in Zaria, Nigeria”. Sci. World J. 2009, 7-9.

[18] Ndams, I.S., Joshua, I.A., Luka, S.A and Sadiq, H.O "Epidemiology of hepatitis B infection among pregnant women in Minna, Nigeria”. Sci. World J. 2008, 3(3): 5-8.

[19] Duncan, M.E., Tibaus, G and Pelger, A, "Prevalence and significance of sexually transmitted diseases among women attending clinics in Addis Ababa”. Ethiop. J. Health Dev. 1995, 12: 31-40.

[20] Candotti, D., Danso, K and Allain, J, "Maternal transmission of hepatitis B virus genotype E in Ghana, West Africa”. J. Gen. Virol. 2007, 88: 2686-2695.
[21] WHO/EPI, "Protocol for assessing prevalence of hepatitis B infection in antenatal patients'. 1990, WHO/EPI/GEN/90.6.

[22] Awole, M and Gebre-selassie, S, "Seroprevalence of hepatitis B surface antigen and its risk factors among pregnant women in Jimma, South-west Ethiopia”. Ethiop. J. Health Dev. 2005, 19(1): 45-50.

[23] Ahmedin, J., Taylor, $m$ and Ram, C.T, "A new section in cancer offering timely and targeted information”. Can. J. Clin. 2004, 54: 23-25

[24] Chakravati, A., Rawat, D and Jarin, M, "A study of the perinatal trans-mission of the hepatitis B virus". Ind. J. Med. Microbiol. 2005, 23: 128-130.

[25] Wiseman, E., Fraser, M.A., Holden, S., Glass, A., Bronwynne, L.K., Leon, G.H., Michael, W.M., Ayres, A and Locarnini, S.A, "Perinatal transmission of hepatitis B virus: an Australian experience”. Med. J. Aust. 2009, 190(9): 489-492. 